\title{
A prospectus for future geomorphological investigation of the Namib Sand Sea
}

lan Livingstone (corresponding author)

School of Science and Technology, The University of Northampton, Northampton NN2 6JD, UK ian.livingstone@northampton.ac.uk

Andreas Baas

Department of Geography, King's College London, Strand, London WC2R 2LS, UK andreas.baas@kcl.ac.uk

Mark D. Bateman

Department of Geography, The University of Sheffield, Sheffield S10 2TN, UK m.d.bateman@Sheffield.ac.uk

Charles Bristow

Department of Earth and Planetary Sciences, Birkbeck University of London, Malet Street, London WC1E 7HX, UK

c.bristow@ucl.ac.uk

Robert G. Bryant

Department of Geography, The University of Sheffield, Sheffield S10 2TN, UK

r.g.bryant@sheffield.ac.uk

Joanna E. Bullard

Department of Geography, Loughborough University, Leicestershire, LE11 3TU UK

j.e.bullard@lboro.ac.uk

Joanna M. Nield

Geography and Environment, University of Southampton, Highfield, Southampton SO17 1BJ, UK J.Nield@soton.ac.uk

David S. G. Thomas

School of Geography and Environment, South Parks Road, Oxford OX1 3QY, UK david.thomas@ouce.ox.ac.uk

Kevin H. White

Department of Geography, University of Reading, Whiteknights, Reading RG6 6UD, UK k.h.white@reading.ac.uk

Giles F. S. Wiggs.

School of Geography and Environment, South Parks Road, Oxford OX1 3QY, UK

giles.wiggs@ouce.ox.ac.uk 


\title{
A prospectus for future geomorphological investigation of the Namib Sand Sea
}

\author{
ABSTRACT
}

The Namib Sand Sea in southern Africa offers an ideal location in which to consider general questions about the evolution of sand seas, about the fluxes of sand through contemporary dune fields and about the patterns of dune form that are created. This paper aims to provide a concise account of the approaches and techniques that are currently being used and will be used in the future to address these questions. The paper considers the techniques employed to investigate wind climate, the morphometry of the dunes, the internal structure of dune sediments, the age of the dunes and the potential to model dune development.

Keywords: Namib Desert, sand dune, remote sensing, morphometry, terrestrial laser scanner, ground-penetrating radar, cellular automaton model

\section{INTRODUCTION}

The Namib Sand Sea has been the subject of very considerable geomorphological investigation, reviewed recently by Livingstone (2013) and Stone (2013) as part of the celebrations of the 50th anniversary of the Research and Training Centre at Gobabeb. In a global context, it provides a unique coastal desert dunefield for which sand is supplied by rivers flowing from the continental interior, depositing that sand on the coastline as a source for aeolian transport into the dunefield. Recently recognised as a UNESCO World Heritage Site, the sand sea, which is clearly-delimited, contains dunes of a diverse range of forms and sizes within a relatively small area. Past geomorphological research in the Namib Sand Sea has frequently contributed to global discussions both about categorising dune patterns at the scale of a sand sea and about the development of individual dune forms (Livingstone, 2013). It therefore offers an ideal location in which to consider general questions about the evolution of sand seas, about the fluxes of sand through contemporary dune fields and about the patterns of dune form that are created. This paper aims to provide a concise account of the approaches and techniques that are currently being used and will be used in the future to address these questions. 


\section{METHODS OF INVESTIGATION}

\section{Wind regimes}

Livingstone et al. (2010) identified a significant meteorological data gap within the Namib Sand Sea. This situation is not unusual in arid regions, and a number of workers (e.g. Thomas et al., 2005) have highlighted how limited spatial and temporal coverage of meteorological data can make the calculation of sand flux, dune migration rate and any viable understanding of the implications of future environmental change extremely difficult. Reanalysis data (e.g. ERA-40, NCEP), where calculated surface (at $10 \mathrm{~m}$ height) windfields are generated, are commonly used to fill data gaps where meteorological observations are difficult or where data are absent (e.g. over oceans, Monahan, 2006; over land, Barstad et al., 2009; He et al., 2010). However, where testing of reanalysis data products has been carried out in the Namib (Livingstone et al., 2010), results have suggested that, whilst ERA-40 data (Uppala et al., 2005) provide a useful overview of the regional wind regime, they significantly underestimated a number of components of the observed wind record at a specific location (e.g. Gobabeb, at the north end of the sand sea). This included wind extremes, seasonal variability, and components of annual/inter-annual variability. Uncertainties became more apparent when ERA-40 data were processed to depict sand transport, as omissions of extremes in wind magnitude were shown to have an exponential impact on the calculation of extremes in sand flux.

In order to provide a better understanding of the development of the Namib Sand Sea, two new meteorological stations have now been located in the central and southern sectors of the sand sea. These instruments will provide the first long-term meteorological data recorded in the southern Namib Sand Sea. The data obtained, coupled with near real-time ECMWF interim re-analysis data (which offer improved resolution and enhanced wind-field derivation over ERA40 data; Dee et al., 2011), will enable detailed statistical downscaling of surface wind fields derived from across the Namib Sand Sea for the first time.

\section{Morphometry: remote sensing, surveying and terrestrial laser scanning}

The widespread availability of digital elevation models (DEMs) derived from modern remote sensing data has enabled new morphometric analyses of landforms to take place. Over the past 15 years the field of geomorphometry has undergone "an explosive growth fuelled by the computer revolution and digital elevation models ..." (Pike, 2000, p.1) provided by, among others, new generation satellite and space shuttle data, Lidar data and terrestrial laser scanners (TLS). Aeolian sand dunes 
readily lend themselves to this sort of morphometric analyses, with a particular focus on the relationships between dune height and spacing (Breed \& Grow, 1979; Wasson \& Hyde, 1983; Lancaster, 1988; Wasson et al., 1988; Dong et al., 2004). The determination of dune spacing is rapid and accurate using 2-dimensional aerial photographs and satellite images, but determining dune height is more time-consuming and problematic (Lancaster \& Greeley, 1990). The inter-dependence of dune height, spacing and cross-sectional area was exploited by Wasson and Hyde (1983) to generate information about the amount of sediment contained within different types of dunes, and subsequently combined with information about wind regime to quantify the conditions under which different types of dunes are likely to form.

As part of the Namib Digital Dune Atlas, a dune classification map (Figure 1) was produced (Livingstone et al., 2010), based on the definitions by McKee (1979). The ASTER Global Digital Elevation Model (GDEM) is derived from the stereoscopic capability of the instrument, providing elevation data at $30 \mathrm{~m}$ cell spacing. The ASTER GDEM provides the potential for full three dimensional analysis of dune morphometry. Bullard et al. (2011) used these data to estimate mean dune height, mean dune spacing, and equivalent sand thickness for the whole Namib sand sea (Figure 2). This enabled analysis of how relationships between these parameters vary between and within the different dune types. Now we have a standard way of calculating dune morphometric data from DEM data, the next step is to extend this method to other sand seas which experience different controlling variables (wind regimes, vegetation cover, sand supply, etc.)

Understanding dune interactions and migration rates (Kocurek et al., 2010) requires detailed measurements of not only the whole dunefield, but also of how individual dunes respond to wind events (Baddock et al., 2011; Weaver \& Wiggs, 2011; Wiggs \& Weaver, 2012). Recent developments in $3 \mathrm{D}$ instrument systems mean that these types of measurements are now feasible in small areas of dune fields using repeated ground-based terrestrial laser scanning (TLS) or, in larger sections, using airborne LiDAR (Bullard, 2006; French \& Burningham, 2009). For example repeat seasonal LiDAR measurements of transverse dunes at White Sands, USA, indicate how dune interactions differ depending on the underlying topography and vegetation characteristics (Ewing and Kocurek, 2010; Reitz et al., 2010). Similar repeat measurements in the Namib Sand Sea would help us to answer questions about how the shape and size of linear dunes, and their distance from source areas or topographically steered winds, alters the rate of collisions and interactions for example under different seasonal wind regimes. TLS measurements are important for a more detailed perspective, as they enable single dunes to be studied, generating an event-based (e.g. Nield et al., 2011) or 
seasonal (e.g. Montreuil et al., 2013) sediment balance. When collected with co-located wind measurements, this balance map would elucidate the topographic control of larger bedforms on sedimentation patterns, as well as indicating the most active and stable parts of a dune which could both improve our interpretations of longer term internal structure and dating measurements. These short term surface change measurements can also help inform modelling which has the advantage of being able to test hypotheses and examine potential landscape change over longer periods and different climate forcing.

\section{Ground Penetrating Radar (GPR)}

GPR has been used to investigate the structure of linear dunes in the Namib Sand Sea (Bristow et al., 2000), where imaging sets of cross-strata, their superposition and cross-cutting relationships provide a relative chronology of dune accumulation and intervening stratigraphic breaks (Bristow et al., 2005) and permit an improved understanding of dune migration with 2D and 3D visualisation of dune strata (Bristow et al., 2007). When combined with optical dating, GPR provides a unique insight into dune development and stratigraphy (Bristow et al., 2007). However, the published papers only report results from linear dunes in the northern part of the Namib Sand Sea close to Gobabeb (Figure 3) leaving vast swathes of the sand sea still to be investigated. Potential targets for further research include the linear dunes of the southern half of the sand sea which are reported to be older than those in the north (Bubenzer et al., 2007). In addition, GPR could be used to investigate the stratigraphy of sandy interdunes, as well as the relationships between linear dunes and crossing dunes, or the relationships between linear dunes and star dunes, or star dunes themselves.

\section{Dating}

Luminescence dating is revolutionising knowledge of Late Quaternary dune system evolution, now offering the potential to contribute to debates regarding dune origin and development as well as climate change impacts on system behaviour (Thomas, 2013). Southern African dune systems are amongst the best dated in the world, yet within this, the Namib Sand Sea is remarkably underanalysed to date with only 38 published ages (Livingstone et al., 2010), compared to over 370 for the Kalahari (Thomas \& Burrough, 2013).

The few published studies that there are greatly add to histories of overall accumulation (Bubenzer et al., 2007) and climate change (Stone et al., 2010), and when linked to ground penetrating radar surveys of internal dune structures, to models of dune behaviour and migrations (Bristow, 2005, 2007). Emphasis to date has focussed on the large linear ridges in the Namib, but the diversity of 
dune patterns present suggest that a strategy to encompass a wider set of forms and subsystems would greatly contribute to debates about sediment throughputs and spatial variability in sand sea development and organisation. Now that luminescence assays can be generated quickly with portable field equipment (e.g. Munyikwa et al., 2012), there is great potential to gain valuable infield data that can guide more detailed analyses using conventional laboratory based dating.

\section{Modelling and self-organisation}

The Namib Sand Sea displays a striking variety of dune forms within its domain, including all principal types (barchans, transverse, linear, star) as well as various compound and complex super-positions. This poses exciting challenges and opportunities for computer simulation modelling of such multitype dunefields. Recent years have seen great advances in deterministic coupled airflow-sandtransport modelling of singular dunes (mostly barchans) and assemblies of multiple dunes (barchan swarms, transverse dunefields, star dunes (e.g. Andreotti et al., 2002; Duran et al., 2010)), but such high-resolution simulations are not feasible for the large domain of the Sand Sea, nor for the assortment of multiple types. Cellular Automaton (CA) modelling based on self-organisation principles offers a potential route. The RGS-IBG/BSG Working Group on Sand Seas and Dune Fields explored the use of a typical CA dune model (DECAL; Baas and Nield, 2007) to simulate existing dunes in the Sand Sea and their future evolution, focussing on linear dunes. The modelling was based on data from the Digital Atlas: the DEM and wind regime data (Livingstone et al., 2010). Results showed that self-organised linear dune development could be successfully simulated on the correct spatial scales, and that transverse dunes may invade and transform the linear dunefield in future (WGSSDF, 2010). However, the work raises some fundamental questions about the translation of realistic transport rates to a modelling environment with limited spatial and temporal resolution, and also poses some challenges for deriving required wind climatologies from the available data and the subsequent transformation to drift potentials - issues that are relevant to many projects attempting to implement real-world data in a simulation scenario context. These questions and challenges will be crucial to future attempts at modelling extensive and complex multi-type dunefields like the Namib Sand Sea.

\section{CONCLUSION}

This paper is one of a collection to celebrate Dr. Mary Seely's association with the Namib and the Research and Training Centre at Gobabeb. Throughout her time in Namibia, Dr Seely has been a strong supporter of geomorphological studies in the Namib. When she first arrived at the Centre, 
geomorphological investigations concentrated on local field studies of dune dynamics and surface sediments. Developments in remote sensing technology now allow us, however, to gain a much fuller understanding of the range and morphometry of dunes in the sand sea. They also provide the opportunity to understand the wind climate more fully. Both of these realms of remote sensing, however, still require careful ground truthing. The development of luminescence dating now enables us to examine the age of dunes, and ground-penetrating radar permits us to visualise the internal sedimentary structure of the dunes. In combination, these techniques have told us and will continue to tell us much about the evolution of individual dunes and of the sand sea. Terrestrial laser scanning offers the potential to investigate the response of dune surfaces to wind events, and cellular automaton modelling will allow us to consider the development of the dune patterns at the scale of the sand sea, and to ask 'what if' questions about how the sand sea would respond to a change in wind climate. All of these techniques are currently being employed to consider the key questions about sand seas development, about sand flux and about the dune patterns. 


\section{REFERENCES}

ANDREOTTI, B., CLAUDIN, P \& DOUADY, S. 2002. Selection of dune shapes and velocities. Part 1: Dynamics of sand, wind and barchans. European Physics Journal B 28: 321-339.

BAAS, A.C.W. \& NIELD, J.M. 2007. Modelling vegetated dune landscapes. Geophysical Research Letters 34: L06405

BADDOCK, M.C., WIGGS, G.F.S. \& LIVINGSTONE, I. 2011. A field study of mean and turbulent flow characteristics upwind, over and downwind of barchan dunes. Earth Surface Processes and Landforms 36: 1435-1448.

BARSTAD, I., SORTEBERG, A., FLAT $\varnothing$ Y, F. \& DÉQUÉ, M. 2009. Precipitation, temperature and wind in Norway: dynamical downscaling of ERA40. Climate Dynamics 33(6): 769-776.

BREED, C.S. \& GROW, T. 1979. Morphology and distribution of dunes in sand seas observed by remote sensing. In McKEE, E.D. (ed.) A Study of Global Sand Seas, USGS Professional Paper 1052: 253-403.

BRISTOW, C.S., BAILEY, S.D. \& LANCASTER, N. 2000. The sedimentary structure of linear sand dunes. Nature 406: 56-59.

BRISTOW, C.S., DULLER, G.A.T. \& LANCASTER, N. 2007. Age and dynamics of linear dunes in the Namib Desert. Geology 35: 555-558.

BRISTOW, C.S., LANCASTER, N. \& DULLER, G.A.T. 2005. Combining ground penetrating radar surveys and optical dating to determine dune migration in Namibia. Journal of the Geological Society, London 162: 315-321.

BUBENZER, O., BÖDEKER, O., BESLER, H. 2007, A transcontinental comparison between the southern Namib Erg (Namibia) and the southern Great Sand Sea (Egypt). Zbl. Geol. Paläont. 1: 7-23.

BULLARD, J.E. 2006. Arid geomorphology. Progress in Physical Geography 30: 542-552.

BULLARD, J.E., WHITE, K. \& LIVINGSTONE, I. 2011. Morphometric analysis of aeolian bedforms in the Namib Sand Sea using ASTER data. Earth Surface Processes and Landforms 36: 1534-1549.

DEE, D.P., UPPALA, S.M., SIMMONS, A.J., BERRISFORD, P., POLI, P., KOBAYASHI, S., ANDRAE, U., BALMASEDA, M.A., BALSAMO, G., BAUER, P., BECHTOLD, P., BELJAARS, A.C.M., VAN DE BERG, L., BIDLOT, J., BORMANN, N., DELSOL, C., DRAGANI, R., FUENTES, M., GEER, A.J., HAIMBERGER, L., HEALY, S.B., HERSBACH, H., HÓLM, E.V., ISAKSEN, L., KÅLLBERG, P., KÖHLER, M., MATRICARDI, M., MCNALLY, A.P., MONGE-SANZ, B. M., MORCRETTE, J.-J., PARK, B.-K., PEUBEY, C., DE ROSNAY, P., TAVOLATO, C., THÉPAUT, J.-N. \& VITART, F. 2011. The ERA-Interim reanalysis: configuration and performance of the data assimilation system. Quarterly Journal of the Royal Meteorological Society 137: 553-597. doi: 10.1002/qj.828

DONG, Z., WANG, T. \& WANG, X. 2004. Geomorphology of the megadunes in the Badain Jaran Desert. Geomorphology 60: 191-203. 
DURAN, O., PARTELI, E.J.R. \& HERRMANN, H.J. 2010. A continuous model for sand dunes: Review, new developments and application to barchan dunes and barchan dune fields. Earth Surface Processes and Landforms 35: 1591-1600.

EWING, R.C. \& KOCUREK, G. 2010. Aeolian dune interactions and dune-field pattern formation: White Sands Dune Field, New Mexico. Sedimentology 57: 1199-1219.

FRENCH, J.R. \& BURNINGHAM, H. 2009. Coastal geomorphology: trends and challenges. Progress in Physical Geography 33: 117-129.

HE, Y., MONAHAN, A.H., JONES, C.G., DAI, A., BINER, S., CAYA, D. \& WINGER, K. 2010. Probability distributions of land surface wind speeds over North America. Journal of Geophysical Research: Atmospheres (1984-2012)115(D4).

KOCUREK, G., EWING, R.C., MOHRIG, D. 2010. How do bedform patterns arise? New views on the role of bedform interactions within a set of boundary conditions. Earth Surface Processes and Landforms 35: 51-63.

LANCASTER, N. 1988. Controls of eolian dune size and spacing. Geology 16: 972-975.

LANCASTER, N. \& GREELEY, R. 1990. Sediment volume in the north polar sand seas of Mars. Journal of Geophysical Research 95(B7): 10,921-10,927.

LIVINGSTONE, I. 2013. Aeolian geomorphology of the Namib Sand Sea. Journal of Arid Environments 93: 30-39. doi: 10.1016/j.jaridenv.2012.08.005

LIVINGSTONE, I., BRISTOW, C., BRYANT, R.G., BULLARD, J., WHITE, K., WIGGS, G.F.S., BAAS, A.C., BATEMAN, M.D._\& THOMAS D.S.G. 2010. The Namib Sand Sea Digital Database of aeolian dunes and key forcing variables. Aeolian Research 2: 93-104.

McKEE, E.D. 1979. Introduction to a study of global sand seas. In McKEE, E.D. (ed). A Study of Global Sand Seas, USGA Professional Paper 1052: 1-19.

MONAHAN, A.H. 2006. The probability distribution of sea surface wind speeds. Part II: Dataset intercomparison and seasonal variability. Journal of Climate 19: 521-534.

MONTREUIL, A-L., BULLARD, J.E., CHANDLER, J.H. \& MILLETT, J. 2013. Decadal and seasonal development of embryo dunes on an accreting macrotidal beach: North Lincolnshire, UK. Earth Surface Processes and Landforms 38: 1851-1868.

MUNYIKWA, K., BROWN, S. \& KITABWALLA, Z. 2012. Delineating stratigraphic breaks at the bases of postglacial eolian dunes in central Alberta, Canada using a portable OSL reader. Earth Surface Processes and Landforms 37: 1603-1614.

NIELD, J.M., WIGGS, G.F.S. \& SQUIRRELL, R.S. 2011. Aeolian sand strip mobility and protodune development on a drying beach: examining surface moisture and surface roughness patterns measured by terrestrial laser scanning. Earth Surface Processes and Landforms 36: 513-522.

PIKE, R.J. 2000. Geomorphometry - diversity in quantitative surface analysis. Progress in Physical Geography 42: 1-20. 
REITZ, M.D., JEROLMACK, D.J., EWING, R.C. \& MARTIN, R.L. 2010. Barchan-parabolic dune pattern transition from vegetation stability threshold. Geophysical Research Letters 37: L19402.

STONE, A.E.C., THOMAS, D.S.G. \& VILES, H.A. 2010. Late Quaternary palaeohydrological changes in the northern Namib Sand Sea: new chronologies using OSL dating of interdigitated aeolian and water-lain interdune deposits. Palaeogeography, Palaeoclimatology, Palaeoecology 288: 35-53.

STONE, A.E.C. 2013. Age and dynamics of the Namib Sand Sea: A review of chronological evidence and possible landscape development models. Journal of African Earth Sciences 82: 70-87.

THOMAS, D.S.G. 2013. Reconstructing palaeoenvironments and palaeoclimates in drylands: what can landform analysis contribute? Earth Surface Processes and Landforms 38: 3-16.

THOMAS, D.S.G., KNIGHT, M. \& WIGGS, G.F.S. 2005. Remobilization of southern African desert dune systems by twenty-first century global warming. Nature 435: 1218-1221.

THOMAS, D.S.G. \& BURROUGH, S.L. 2013. Luminescence-based dune chronologies in southern Africa: analysis and interpretation of dune database records across the subcontinent. Quaternary International. doi.org/10.1016/j.quaint.2013.09.008

WASSON, R.J. \& HYDE, R. 1983. Factors determining desert dune type. Nature 304: 289-303.

WASSON, R.J., FITCHETT, K., MACKEY, B. \& HYDE, R. 1988. Large-scale patterns of dune type, spacing and orientation in the Australian continental dunefield. Australian Geographer 19: 89-104.

WEAVER, C.M \& WIGGS, G.F.S. 2011. Field measurements of mean and turbulent airflow over a barchan sand dune. Geomorphology 128: 32-41.

WIGGS, G.F.S. \& WEAVER, C.M. 2012. Turbulent flow structures and aeolian sediment transport over a barchan sand dune. Geophysical Research Letters 39: L05404.

WORKING GROUP ON SAND SEAS AND DUNE FIELDS, RGS-IBG/BSG 2010 Using the Namib digital atlas to model the future, oral presentation, Global Sand Seas: Past, Presence, and Future; London, October 2010.

UPPALA, S.M., KALLBERG, P.W. \& SIMMONS, A.J. 2005. The ERA-40 re-analysis. Quarterly Journal of the Royal Meteorological Society 131: 2961-3012. 


\section{FIGURE CAPTIONS}

Figure 1. Distribution of different dune types in the Namib Sand Sea (after Livingstone et al., 2010) and locations of Visitors Dune (VD), Warsaw (WW), Rooibank (RBK), Narabeb (NBB), Flodden Moor (FM).

Figure 2. Spatial variation in dune height, spacing and equivalent sand thickness throughout the Namib Sand Sea generated using ASTER GDEM data (Bullard et al., 2011).

Figure 3. Three-dimensional visualisation of dune cross-strata imaging the contact between a linear dune and a superimposed transverse dune collected with $200 \mathrm{MHz}$ GPR antennas, Warsaw Dune, Namibia (modified from Bristow et al., 2007). 